\title{
Pengaruh Ekstrak Daun Sirsak terhadap Ekspresi CD8 pada Populasi Limfosit Tumor Payudara Tikus Sprague Dawley
}

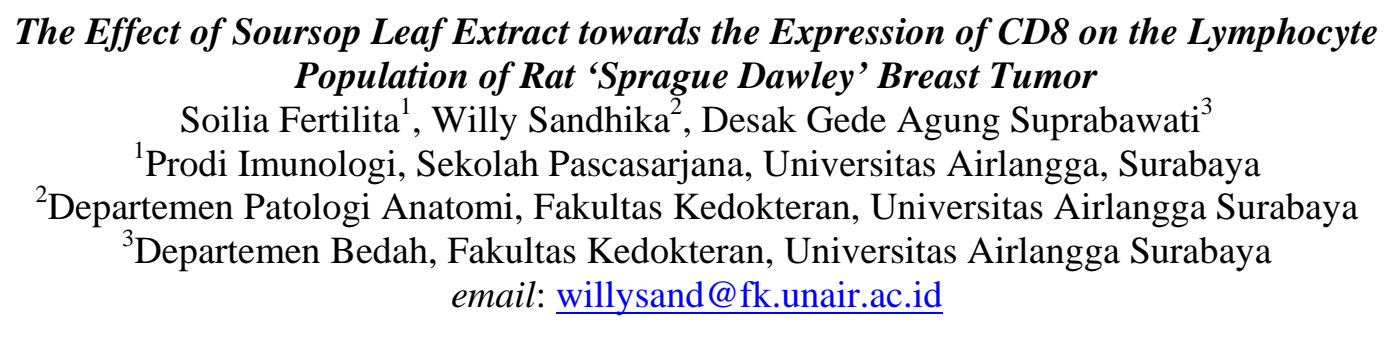

\begin{abstract}
ABSTRAK
Perubahan klinis pada payudara sebagian besar bersifat jinak, hanya 3 - 6\% merupakan keganasan payudara. Namun demikian, kanker payudara menjadi perhatian utama mengingat angka kejadian yang terus menerus meningkat serta morbiditas dan mortalitas yang tinggi. Pengobatan kanker hingga saat ini masih menjadi tantangan. Hal ini membuka peluang penelitian terapi kanker terutama dari bahan herbal. Daun sirsak telah banyak digunakan masyarakat secara tradisional untuk pengobatan tumor. Di samping itu berbagai studi juga telah menunjukkan efek sitotoksik tanaman ini terhadap berbagi cell line kanker. Namun demikian belum ada penelitian yang menganalisis efek ekstrak daun sirsak terhadap populasi limfosit di lingkungan mikro tumor terutama yang berfungsi pada respon imun anti tumor. Penelitian bertujuan untuk mengetahui infiltrasi sel limfosit T CD8 pada jaringan tumor yang payudara tikus Spraque Dawley yang diberikan ekstrak etanol daun sirsak. Ekspresi CD8 dianalisis melalui pewarnaan imunohistokimia. Ekspresi CD8 positif ditandai dengan warna coklat pada sitoplasma sel limfosit, selanjutnya ekspresi CD8 dari setiap sampel dihitung pada 3 lapang pandang dengan high-power field, kemudian ditentukan nilai rata-ratanya. Pewarnaan HE menunjukkan variasi infiltrasi limfosit pada nodul payudara tikus SD. Rata-rata ekspresi CD8 kelompok kontrol menunjukkan hasil lebih tinggi dibandingkan kelompok perlakuan. Namun demikian, hasil uji komparasi menunjukkan tidak ada perbedaan bermakna ( $p>0,05)$ antara ekspresi CD8 kelompok kontrol dengan perlakuan. Hasil ini menunjukkan bahwa pemberian ekstrak daun sirsak tidak menyebabkan perbedaan bermakna ekspresi CD8 pada populasi limfosit yang menginfiltrasi tumor payudara tikus SD.
\end{abstract}

Kata kunci : CD8, Nodul Payudara, Spraque Dawley, Daun Sirsak

\section{ABSTRACT}

Clinical changes to breast mostly are benign; the malignancies of the breast is only around $3-6 \%$. Nevertheless, breast cancer becomes a main concern following the increasing of its occurrence number as well as a high rate of morbidity and mortality. Treatment on cancer is still a challenge to this time. It instigates an open opportunity towards the research of cancer therapy especially derived from herbal materials. Soursop leaf has been widely used by the community for traditional medication, including tumor. Furthermore, several researches also have shown its cytotoxic effect towards various 'cell line' of cancer. However, there is no research analyzing the effect of soursop leaf extract towards the population of lymphocyte in the environment of micro-tumor, particularly functioning on the response of anti-tumour immune. This research aims to realize the infiltration of lymphocyte cell T CD8 to the tissues of rat 'Sprague Dawley' (SD) breast tumor, with given ethanol extract of soursop leaves. The expression of CD8 is examined through the immunohistochemical staining. The positive expression of CD8 is marked by the brown color of lymphocyte cytoplasm cells. Thereafter, the expression of each sample is calculated to the three fields of view with high-power field, to be then its average value determined. The ' $H E$ ' staining indicates the various lymphocyte infiltration on the SD breast nodules. The control group's expression of CD8 mostly 
Soilia Fertilita, Willy S., Desak Gede Agung S.: Pengaruh Ekstrak Daun Sirsak terhadap Ekspresi CD8...

shows a higher result than the treatment group's. However, the result of comparative test denotes no significant difference ( $p>0.05$ ) between the control group's expression of CD8 and the treatment group's. All these results indicate that the soursop leaf extract causes no significant difference towards the expression of CD8 on the population of lymphocyte infiltrating the rat 'Sprague Dawley' breast tumor.

Keywords: CD8, Breast Nodule, Sprague Dawley, Soursop Leaf

\section{PENDAHULUAN}

Nodul pada payudara merupakan keluhan yang sering menimbulkan kekhawatiran pada sebagian besar wanita. Hal ini disebabkan karena adanya kemungkinan nodul yang muncul adalah suatu keganasan payudara. Sebagian besar perubahan klinis pada payudara adalah jinak. Data di Amerika menunjukkan lebih dari 1 juta wanita memiliki hasil biopsi payudara jinak. Hanya 3 - $6 \%$ kasus disebabkan oleh kanker payudara (Stachs et al. 2019; Visscher et al. 2014). Di Indonesia, kanker payudara menempati urutan pertama dengan estimasi insiden 40 per 100.000 perempuan. Data dari RS. Dharmais tahun 2010 - 2013 menunjukkan bahwa kanker payudara, kanker servik, dan kanker paru merupakan kanker dengan penderita terbanyak, dimana kasus baru dan kematian akibat kanker tersebut terus menerus meningkat (Pusat Data dan Informasi, 2015). Hal ini menyebabkan kanker payudara mendapatkan perhatian utama karena angka kejadian yang terus meningkat serta morbiditas dan mortalitas yang tinggi.

Hingga saat ini berbagai terapi kanker payudara terus dikembangkan diantaranya terapi pembedahan, radioterapi, kemoterapi, terapi hormon, dan imunoterapi (Anjum et al., 2017). Namun demikian, kasus metastasis kanker, kekambuhan, bahkan pemulihan pada kanker primer masih menjadi tantangan pada terapi kanker (Kalra and Edwards 2012). Hal ini membuka peluang pengembangan berbagai terapi kanker termasuk dari bahan herbal.

Sirsak (Annona muricata) merupakan tanaman yang telah dikenal secara luas di masyarakat dan digunakan dalam pengobatan tradisional termasuk pengobatan kanker. Bagian dari tanaman ini yang paling banyak digunakan untuk pengobatan adalah daunnya. Sirsak mengandung annonacin yang banyak terdapat pada daun yang diketahui memiliki efek sitotoksik terhadap sel kanker. Di samping itu kemampuan modulasi sistem imun ekstrak daun sirsak juga telah dilaporkan. Salah satunya studi oleh Najmuddin et al yang menunjukkan peningkatan populasi sel $\mathrm{T} \mathrm{CD}^{+}, \mathrm{CD}^{+}$dan sel NK 1.1 pada lien mencit yang diinduksi kanker payudara dan diberikan ekstrak kasar daun sirsak (Najmuddin et al. 2016). 
Tumor Infiltrating Limfosit (TIL) merupakan kelompok sel limfosit (limfosit T sitotoksik $\left(\mathrm{CD}^{+}\right)$, T helper, T regulator, dan sel natural killer) yang menginfiltrasi tumor. Secara histologi, sel-sel limfosit ini dapat ditemukan di daerah stromal, peritumoral, maupun intratumoral. Infiltrasi sel limfosit terutama bertujuan untuk menstimulasi respon imun terhadap tumor (Barnes et al., 2017). Diantara komponen TIL, sel limfosit T CD8 ${ }^{+}$ (sitotoksik) merupakan komponen TIL yang paling penting karena memiliki peran dominan dalam imunitas anti kanker serta berfungsi untuk mengenali dan menghancurkan sel tumor. Interaksi limfosit T sitotoksik dan sel tumor telah dikemukakan pada berbagai studi. Hasilnya menunjukkan bahwa infiltrasi dari limfosit $\mathrm{T} \mathrm{CD}^{+}$yang tinggi dan penanda sitotoksik lainnya dihubungkan dengan luaran klinis pasien yang baik pada berbagai tumor termasuk tumor payudara (Giraldo et al. 2015). Namun demikian studi yang menganalisis efek daun sirsak terhadap respon imun anti tumor terutama berdasarkan infiltrasi limfosit T CD8 ${ }^{+}$di lingkungan mikro tumor masih belum ada. Oleh karena itu, penelitian ini bertujuan untuk melihat gambaran infiltrasi limfosit T CD8+ di jaringan tumor payudara tikus Spraque Dawley yang diberikan ekstrak etanol daun sirsak.

\section{METODE}

Peneliti telah mendapatkan sertifikat kelaikan etik dari Komisi Etik Penelitian Fakultas Kedokteran Hewan Universitas Airlangga, dengan nomor sertifikat 2.KE.021.02.2019. Jenis penelitian adalah eksperimental laboratorium dan rancangan yang digunakan adalah true experimental design dengan post test only control group design. Sampel penelitian adalah 21 nodul payudara dari 13 ekor tikus putih (Rattus norvegicus) betina galur Spraque Dawley (SD).

Instrumen yang digunakan pada peneliti terdiri dari oven, blender, waterbath, rotary microtom, decloaking chamber (Biocare) digunakan pada proses antigen retrieval, inkubator, staining jar, humidity chamber, dan mikroskop cahaya untuk pengamatan preparat. Pembuatan model hewan kanker payudara menggunakan 7,12-dimethylbenz (a) anthracene (DMBA) Sigma-Aldrich yang dilarutkan dalam minyak jagung. Pembuatan ekstrak etanol daun sirsak menggunakan daun sirsak segar dan alkohol 96\% sebagai pelarut. Sedangkan untuk fiksasi jaringan tumor payudara, pembuatan blok parafin, pewarnaan hematoksilin eosin (HE), dan pewarnaan imunohistokimia (IHK) menggunakan buffer formalin 10\%, parafin, xylene, alkohol absolut, 95\%, 90\%, 80\%, $70 \%$, dan 50\%, aquades, alkohol asam, larutan hematoksilin, larutan eosin $1 \%$, mounting medium DPX (distyrene- plasticiser-xylene), $\mathrm{H}_{2} \mathrm{O}_{2} 30 \%$, metanol, phosphate- buffered 
Soilia Fertilita, Willy S., Desak Gede Agung S.: Pengaruh Ekstrak Daun Sirsak terhadap Ekspresi CD8...

saline (PBS), background sniper, diamino benzidine tetrahydro chloride (DAB), betazoid DAB substrat buffer, trek avidin-HRP label, imunoglobulin rabit anti rat, dan imunoglobulin anti CD8.

Pembuatan ekstrak dilakukan dengan teknik maserasi menggunakan pelarut etanol 96\%. Daun sirsak dibersihkan kemudian dikeringkan menggunakan oven pada suhu $40^{\circ} \mathrm{C}$. Simplisia diblender dan diayak hingga menjadi serbuk. Selanjutnya, serbuk daun sirsak direndam dengan kurang lebih 5 liter etanol 96\% hingga seluruhnya terendam, kemudian didiamkan selama 24 jam dalam keadaan tertutup rapat. Rendaman disaring hingga membentuk ekstrak cair, kemudian diuapkan 3 kali pengulangan diatas waterbath hingga menjadi ekstrak kental.

Persiapan hewan uji dimulai dengan aklimatisasi selama tujuh hari sebelum induksi dimulai. Pembuatan model hewan tumor payudara dengan pemberian DMBA 20 mg/KgBB secara intragastrik, 2 kali seminggu selama 5 minggu. Tikus SD dibagi kedalam 3 kelompok pengamatan yaitu, kelompok kontrol (tidak mendapat perlakuan), kelompok perlakuan 1 dan 2 yang masing-masing mendapatkan ekstrak etanol daun sirsak dosis $600 \mathrm{mg} / \mathrm{kgBB}$ dan $300 \mathrm{mg} / \mathrm{KgBB}$ selama 28 hari.

Gambaran histopatologi dari nodul payudara yang terbentuk diamati dengan pewarnaan hematoksilin eosin (HE), sedangkan pemeriksaan imunohistokimia digunakan untuk menilai ekspresi CD8 pada populasi limfosit yang menginfiltrsi tumor. Antibodi primer untuk pemeriksaan CD8 menggunakan purified anti-rat CD8a yang merupakan mouse monoclonal IgG1 produksi Biolegend. Ekspresi CD8 positif ditandai dengan warna coklat pada sitoplasma sel limfosit, selanjutnya ekspresi CD8 dari setiap sampel dihitung pada 3 lapang pandang dengan high-power field, kemudian ditentukan nilai rataratanya.

\section{HASIL}

Tiga belas ekor tikus SD betina diinduksi DMBA intragastrik untuk membuat model hewan tumor payudara. Proses pembuatan model hewan tumor payudara dengan metode induksi DMBA intragastrik menghasilkan jumlah dan lokasi nodul yang bervariasi. Pada penelitian, setiap ekor tikus SD dapat terbentuk 1 - 4 nodul, sehingga diperoleh 21 unit nodul payudara dari 13 ekor tikus. Tikus yang telah terbentuk nodul dengan ukuran besar dari $1 \mathrm{~cm}$, dibagi kedalam 3 kelompok, yaitu kelompok kontrol, kelompok perlakuan 1 (P1) diberikan ekstrak etanol daun sirsak dosis 600 mg/kg BB dan kelompok perlakuan 2 (P2) diberikan ekstrak etanol daun sirsak dosis 300 mg/kg BB. 
Setelah perlakuan, tikus diterminasi, nodul dieksisi dan difiksasi dalam buffer formalin $10 \%$ untuk selanjutnya dibuat blok parafin.

Pewarnaan HE dilakukan untuk melihat gambaran histopatologi nodul payudara yang terbentuk. Dari 21 nodul, 17 nodul memiliki gambaran histopatologi Invasive ductal carcinoma dan hanya 4 nodul dari kelompok P2 yang memiliki gambaran sclerosing adenosis (Tabel 1).

\section{Tabel 1. Karakteristik Nodul Payudara Setelah Induksi DMBA}

\begin{tabular}{lccr}
\multicolumn{1}{c}{ Kelompok } & $\begin{array}{c}\text { Jumlah Tikus } \\
\text { SD }\end{array}$ & $\begin{array}{c}\text { Jumlah } \\
\text { Nodul }\end{array}$ & Gambaran Histopatologi \\
\hline $\mathrm{K}$ & 6 & 8 & Invasive ductal carcinoma \\
$\mathrm{P} 1$ & 4 & 6 & Invasive ductal carcinoma \\
$\mathrm{P} 2 \mathrm{a}$ & 2 & 3 & Invasive ductal carcinoma \\
$\mathrm{P} 2 \mathrm{~b}$ & 1 & 4 & sclerosing adenosis \\
\hline
\end{tabular}

Pewarnaan HE selain memberikan gambaran histopatologi dari nodul payudara juga dapat memberikan informasi mengenai gambaran umum infiltrasi limfosit pada tumor baik di daerah stroma maupun intratumoral. Hasilnya, secara umum sampel menunjukkan infiltrasi limfosit yang berbeda. Namun terdapat juga nodul, dimana selain limfosit ditemukan infiltrasi sel plasma yang cukup banyak pada stroma.

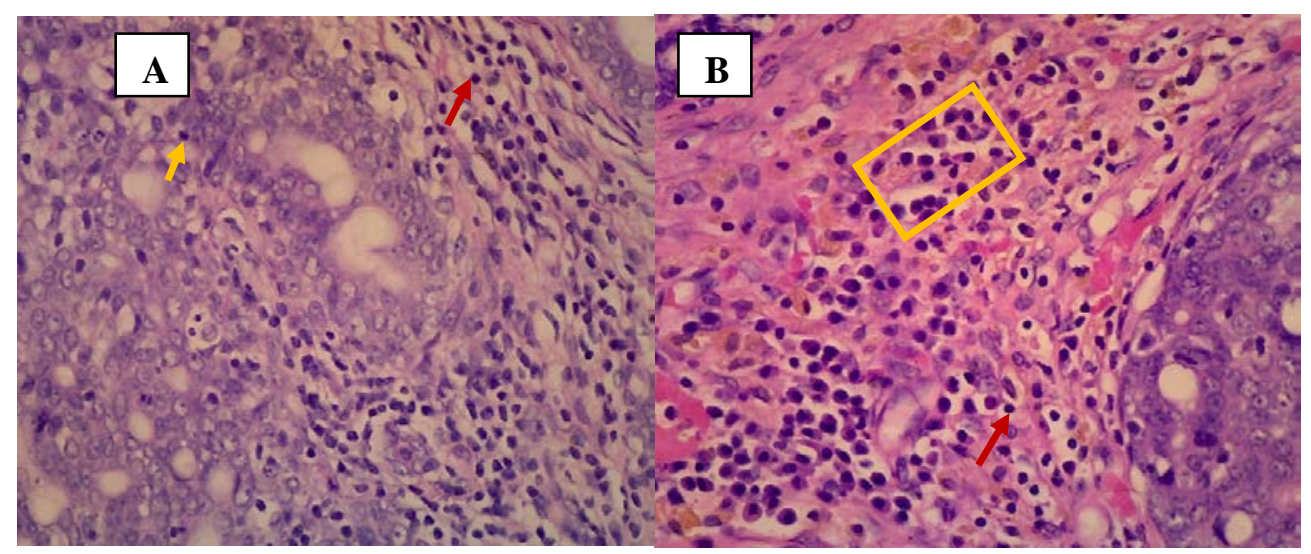

Gambar 1. A. Infiltrasi limfosit pada jaringan kanker payudara tikus SD. Tampak limfosit pada stroma (panah merah) dan intratumoral (panah kuning). B. Infiltrasi sel plasma pada stroma jaringan kanker. Tampak dominasi sel plasma pada stroma (kotak kuning), namun masih terdapat sel limfosit (panah merah).

Pewarnaan imunohistokimia dilakukan untuk melihat ekspresi $\mathrm{CD}^{+}$pada membran sel limfosit yang menginfiltrasi tumor. Ekspresi $\mathrm{CD}^{+}$ditandai dengan warna coklat pada sitoplasma sel limfosit. 


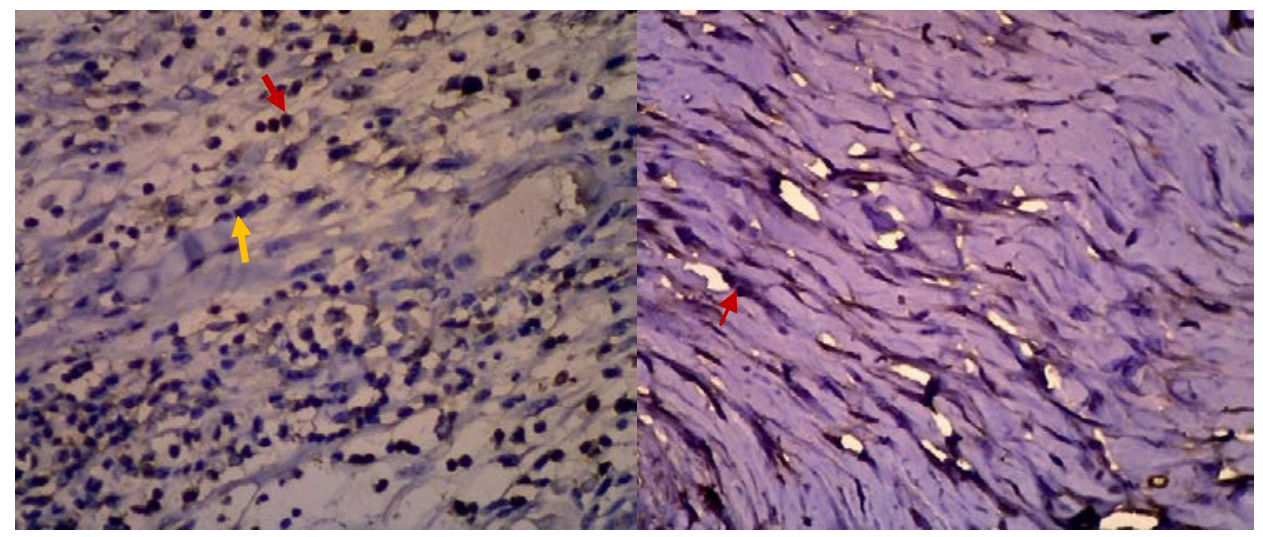

Gambar 2. Ekspresi $\mathrm{CD}^{+}$pada IDC (A) dan sklerosing adenosis (B) dengan pemeriksaan imunohistokimia. Tampak $\mathrm{CD}^{+}$positif pada sitoplasma dimana sel berwarna coklat (panah merah), sedangkan limfosit dengan sitoplasma berwarna biru menunjukkan ekspresi negatif (panah kuning). Pengamatan dilakukan di bawah mikroskop dengan perbesaran 400x.

Jumlah limfosit $\mathrm{T}_{\mathrm{CD}}{ }^{+}$dihitung pada 3 lapang pandang dengan ekspresi terbanyak. Hasil penghitungan, menunjukkan bahwa ekspresi CD8 terbanyak terdapat pada kelompok kontrol, sedangkan ekspresi CD8 paling sedikit ditemukan pada kelompok dengan gambaran histopatologi adenosis. Menariknya, ekspresi CD8 ditemukan berbeda pada nodul yang berasal dari tikus SD yang sama.

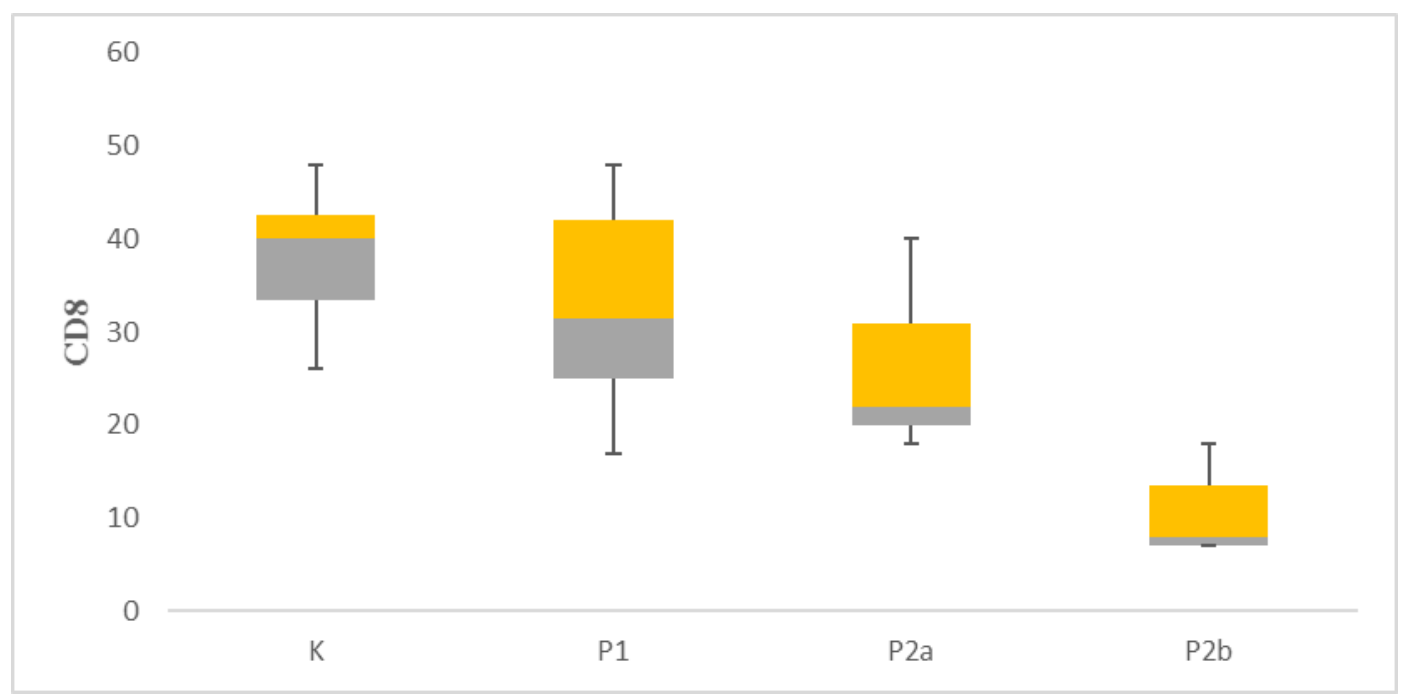

Gambar 3. Ekspresi CD8 pada Setiap Kelompok Penelitian

Uji komparasi dilakukan untuk melihat perbandingan ekspresi CD8 antara kelompok kontrol dengan perlakuan dan kelompok perlakuan 1 dan 2a . Hasilnya tidak 
terdapat perbedaan bermakna $(\mathrm{p}>0,05)$ pada ekspresi CD8 kelompok kontrol dengan perlakuan dan kelompok perlakuan P1 dengan P2a.

Tabel 2. Uji Komparasi Ekspresi CD8 Kelompok Kontrol dan Perlakuan

\begin{tabular}{lcccc}
\hline \multicolumn{1}{c}{ Kelompok } & $\begin{array}{c}\text { Jumlah } \\
\text { Sampel }\end{array}$ & Rata-rata & $\begin{array}{c}\text { Standar } \\
\text { Deviasi }\end{array}$ & Nilai p \\
\hline $\mathrm{K}$ & 8 & 38,25 & 7,31 & 0,27 \\
$\mathrm{P} 1$ & 6 & 32.50 & 11,43 & \multirow{2}{*}{0,08} \\
\hline $\mathrm{K}$ & 8 & 38,25 & 7,31 & \multirow{2}{*}{0,49} \\
$\mathrm{P} 2 \mathrm{a}$ & 3 & 26,67 & 11,72 & \\
\hline P1 & 6 & 32,50 & 11,43 & 11,72 \\
\hline
\end{tabular}

\section{PEMBAHASAN}

Hewan coba yang digunakan untuk membuat model hewan kanker payudara adalah tikus putih betina galur Spraque dawley (SD) usia 4 minggu. Pemilihan tikus SD karena tikus terutama galur SD dan Wistar-Furth rentan bertransformasi jika diinduksi karsinogen kimia salah satunya DMBA (Barros et al. 2004). Metode induksi dengan DMBA intragastrik untuk pembuatan model hewan kanker payudara telah banyak dilakukan. Pada penelitian ini, DMBA diberikan dengan dosis 20 mg/kgBB 2 kali seminggu selama 5 minggu. Berdasarkan penelitian Wongso dkk induksi kanker dengan DMBA dosis $20 \mathrm{mg} / \mathrm{KgBB} 2$ kali seminggu memberikan waktu tercepat terbentuknya nodul payudara pada tikus SD usia 4 minggu. Ada beberapa faktor yang telah diketahui mempengaruhi keberhasilan terjadinya kanker melalui induksi DMBA yaitu stok, umur, musism, jenis kelamin, dan dosis karsinogen (Wongso et al., 2013).

Ekstrak etanol daun sirsak dibuat dengan metode maserasi menggunakan pelarut etanol 96\%. Dari berbagai studi diketahui bahwa senyawa utama pada daun sirsak yaitu acetogenin (annonacin termasuk kelompok acetogenin), alkaloid, dan fenol memiliki efek sitotoksik terhadap berbagai cell line kanker termasuk kanker payudara, dimana acetogenin memiliki efek paling utama. Studi oleh Setyorini dkk yang mengukur kadar annonacin pada ekstrak daun sirsak memberikan hasil 12,8\% (Setyorini et al. 2016).

Hasil pewarnaan HE menunjukkan bahwa 81,82 \% nodul memiliki gambaran histopatologi Intra Ductal Carsinoma (IDC) dan sisanya 18,18 \% menunjukkan gambaran sklerosing adenosis. Pada manusia, sebagian besar tumor payudara juga berasal dari epitel duktal (80\%) dengan gambaran IDC.

Jumlah limfosit $\mathrm{CD}^{+}$yang menginfiltrasi tumor dari setiap kelompok pengamatan menunjukkan hasil yang bervariasi. Menariknya variasi ini juga terlihat pada 
Soilia Fertilita, Willy S., Desak Gede Agung S.: Pengaruh Ekstrak Daun Sirsak terhadap Ekspresi CD8...

jaringan kanker yang berasal dari tikus yang sama dengan nodul berbeda. Namun demikian ekspresi $\mathrm{CD}^{+}$antara kelompok kontrol dengan perlakuan tidak menunjukkan perbedaan bermakna ( $\mathrm{p}>0,05)$. Rata-rata ekspresi CD8 tertinggi ditunjukkan oleh kelompok kontrol dengan rerata 38,25 \pm 7,3 diikuti oleh kelompok P1 dan P2a. Sedangkan kelompok P2b dengan gambaran sklerosis adenosis memiliki jumlah limfosit $\mathrm{T} \mathrm{CD}^{+}$paling rendah. Hasil ini mungkin disebabkan perbedaan respon imun setiap individu pada awal terbentuknya kanker karena terdapat berbagai faktor yang mempengaruhi infiltrasi dan lokalisasi limfosit ke jaringan tumor, perbedaan waktu terbentuknya nodul, perbedaan karakter molekular dari kanker payudara yang terbentuk, dan keterbatasan jumlah sampel.

Infiltrasi limfosit $\mathrm{T}$ dipengaruhi oleh berbagai faktor, yaitu kecocokan reseptor kemokin pada sel $\mathrm{T}$ dengan kemokin yang disekresikan pada lingkungan mikro tumor, penyimpanagn pembuluh darah dan anergi endotelial, serta mekanisme imunosupresif tumor pada sel di lingkungan mikro tumor (Maimela, Liu, and Zhang 2019). Limfosit T yang telah teraktivasi akan meninggalkan organ limfoid sekunder oleh karena ikatan SIP suatu lipid kemotraktan dengan reseptornya SIPR1 (Spingosin I Phosphat Receptor 1) yang diekspresikan di permukaan sel T (Abbas, Lichtman, and Pillai 2018). Faktor lain yang juga berpengaruh pada migrasi sel $\mathrm{T}$ ke jaringan target adalah interaksi reseptor kemokin pada sel $\mathrm{T}$ dengan kemokin yang disekresikan oleh sel tumor dan sel lainnya di lingkungan mikro tumor. Salah satu reseptor kemokin yang diekspresikan sel T CD8 ${ }^{+}$ teraktivasi adalah CXCR3 yang akan berikatan dengan CXCL9, CXCL10, dan CXCL11. Beberapa sel tumor mengekspresikan kemokin ini dalam level yang rendah sehingga menurunkan infiltrasi sel $\mathrm{T} \mathrm{CD8}^{+}$ke lingkungan mikro tumor (Maimela, Liu, and Zhang 2019).

Integrin LFA-1 dan VLA-4 yang merupakan ligand untuk E dan P-selektin suatu molekul adesi serta CD44 suatu reseptor untuk molekul matirks ekstraseluler hialuronan juga mempengaruhi proses migrasi sel $\mathrm{T}$. Ikatan CD44 dengan ligandnya akan mempertahankan sel efektor di jaringan target. Disamping itu, respon sel $\mathrm{T}$ dapat diamplifikasi melalui ikatan CD40L yang diekspresikan oleh sel T dengan CD40 yang diekspresikan oleh sel dendritik sehingga dapat mengaktivasi sel dendritik untuk menjadi APC yang lebih baik. IL-2 yang merupakan T Cell Growth Factor (TCGF) juga berperan pada proliferasi sel $\mathrm{T}$ dan mempertahankan regulator fungsional sel $\mathrm{T}$ (Abbas, Lichtman, and Pillai 2018). 
Infiltrasi CD8 pada populasi limfosit yang menginfiltrasi tumor juga bervariasi pada kasus kanker payudara manusia. Berdasarkan konsensus International TILs Working Group 2014, kanker payudara dibedakan atas 3 grup berdasarkan infiltrasi limfosit ke jaringan tumor. Grup A dengan infiltrasi limfosit rendah (0 - 10\% stroma TIL), grup B dengan infiltrasi limfosit intermediet (10 - 40\% stroma TIL), dan grup C dengan infiltrasi limfosit tinggi (40 - 90\% stroma TIL) (Zgura et al. 2018). Di samping itu berbagai penelitian juga memberikan bukti bahwa terdapat perbedaan infiltrasi limfosit termasuk CD8 pada fenotip kanker payudara yang berbeda.

Penelitian oleh Glajcar et al. (2019) menunjukkan bahwa komposisi infiltarsi sel T pada kanker payudara primer yang invasif berbeda berdasarkan subtipe molekular dari kanker tersebut. Perbedaan komposisi infiltrasi sel $\mathrm{T}$ ini dihubungkan dengan status HER2, derajat dan tipe histologi tumor serta diduga juga berhubungan dengan progresifitas fenotip luminal dan non luminal. Lebih lanjut pada penelitian ini ditemukan bahwa infiltrasi $\mathrm{CTL}\left(\mathrm{CD}^{+}\right)$pada invasive lebih tinggi pada kanker payudara triple negative dan HER2+ non luminal dibandingkan subtipe luminal A. HER2+ berhubungan dengan level TIL yang lebih tinggi dibanding fenotip luminal B. Sedangkan infiltrasi CTL (CD8 ${ }^{+}$) dan Treg lebih tinggi pada luminal A dibandingkan luminal B. Hasil ini selaras dengan studi oleh Mohamed et al. (2016) dimana ditemukan korelasi yang kuat antara TIL CD8 dengan kanker payudara HER2/neu positif. Pada studi ini ditemukan jumlah TIL CD8 lebih tinggi pada HER2/neu positif dibanding HER2/neu negatif. Studi lain oleh Miyoshi et al. (2019) tentang distribusi TIL pada pasien kanker payudara ER+/HER2- menunjukkan bahwa terdapat hubungan antara distribusi TIL dengan status reseptor estrogen dan progesteron sel tumor pada kelompok non rekuren (tidak terjadi rekurensi > 10 tahun). Dimana ditemukan peningkatan TIL pada status ER dan PgR yang lebih tinggi. Hal ini jelas menunjukkan bahwa perbedaan subtipe molekular pada kanker payudara berhubungan dengan perbedaan infiltrasi limfosit terutama TIL CD8 pada kanker tersebut. Namun pada penelitian ini tidak dilakukan pemeriksaan karakteristik molecular dari nodul payudara yang terbentuk, sehingga tidak diketahui apakah penurunan ekspresi CD8 pada kelompok perlakuan dibandingkan kontrol berhubungan dengan fenotip tumor payudara tertentu.

Studi oleh Chen et al. (2018) menunjukkan bahwa terdapat perbedaan infiltrasi sel $\mathrm{T} \mathrm{CD8}^{+}$pada parental tumor dan resisten tumor setelah radioterapi. Terjadi peningkatan sel T CD8 pada parenteral tumor yang tidak diterapi setelah diberikan radioterapi. Namun sebaliknya hanya ditemukan sedikit sel $\mathrm{T} \mathrm{CD8}^{+}$pada resisten tumor 
Soilia Fertilita, Willy S., Desak Gede Agung S.: Pengaruh Ekstrak Daun Sirsak terhadap Ekspresi CD8...

baik yang diterapi maupun yang tidak diterapi. Lebih lanjut penelitian ini menunjukkan bahwa terdapat perbedaan ekspresi kemokin sel T setelah irradiasi pada parenteral tumor dan resisten tumor sehingga mempengaruhi migrasi sel T CD8 ke jaringan tumor (Chen et al. 2018).

Penelitian ini memiliki desain post test only control group design, sehingga kondisi kanker pada tikus sebelum perlakuan tidak diketahui baik dari segi gambaran histopatologi maupun respon imun yang terbentuk sebelumnya. Hal ini menyebabkan efek ekstrak terhadap infiltrasi limfosit CD8 sebelum dan sesudah perlakuan tidak dapat dibandingkan. Ketika nodul kanker terbentuk dan terdiagnosis secara klinis, maka pada saat itu kanker sudah berada pada fase escape dimana respon imun protumor lebih dominan dibandingkan respon imun anti tumor. Di sisi lain, respon imun yang terbentuk sebelumnya sangat ditentukan oleh kondisi setiap host sehingga sangat mungkin menunjukkan gambaran yang berbeda pada setiap individu.

\section{SIMPULAN}

Pemberian ekstrak etanol daun sirsak tidak menunjukkan perbedaan bermakna ekspresi CD8 pada populasi limfosit yang menginfiltrasi tumor payudara tikus SD antara kelompok kontrol dengan yang mendapatkan ekstrak etanol daun sirsak dosis $600 \mathrm{mg} / \mathrm{Kg}$ $\mathrm{BB}$, kelompok kontrol dengan yang mendapatkan ekstrak etanol daun sirsak dosis 300 $\mathrm{mg} / \mathrm{Kg} \mathrm{BB}$, dan kelompok yang mendapatkan ekstrak etanol daun sirsak dosis $600 \mathrm{mg} / \mathrm{Kg}$ BB dengan yang mendapatkan ekstrak etanol daun sirsak dosis 300 mg/Kg BB.

\section{UCAPAN TERIMA KASIH}

Penelitian ini didanai oleh DRPM Dikti melalui skema Penelitian Tesis Magister. Terima kasih kepada Dr. Theresia Indah Budhy S., drg., M.Kes sebagai Ketua Program Studi Imunologi, Sekolah Pascasarjana, Universitas Airlangga, Surabaya.

\section{DAFTAR PUSTAKA}

Abbas, Abdul K;Lichtman, Andrew H;Pillai, Shiv. 2018. Cellular and Molecular Immunology. 9th ed. Elsevier. http://www.elsevier.com/permission.

Anjum, Fakhsheena, Nighat Razvi, and M Ali Masood. 2017. "Breast Cancer Therapy: A Mini Review Breast Cancer Therapy: A Mini Review.” MOJ Drug Des Develop Ther 1(2): 1-5.

Barnes, Tristan A, and Eitan Amir. 2017. "HYPE or HOPE: The Prognostic Value of Infiltrating Immune Cells in Cancer.” British Journal of Cancer 117(4): 451-60.

Barros, Alfredo Carlos S D et al. 2004. "Induction of Experimental Mammary Carcinogenesis in Rats with 7 , 12- Dimethylbenz ( A ) Anthracene.” Rev. Hosp. Clin. Fac. Med. S. Paulo 59(5): 257-61. 
Chen, Hai yan et al. 2018. "Inhibiting the CD8+ T Cell Infiltration in the Tumor Microenvironment after Radiotherapy Is an Important Mechanism of Radioresistance.” Scientific Reports 8(1): 1-10.

Giraldo, Nicolas A. et al. 2015. "The Immune Response in Cancer: From Immunology to Pathology to Immunotherapy.” Virchows Archiv 467(2): 127-35.

Glajcar, Anna et al. 2019. "The Composition of T Cell Infiltrates Varies in Primary Invasive Breast Cancer of Different Molecular Subtypes as Well as According to Tumor Size and Nodal Status." Virchows Archiv 475: 13-23.

Informasi, Pusat Data dan. 2015. "Situasi Penyakit Kanker.” : 1-6.

Kalra, Jessica, and Lincoln A Edwards. 2012. "Breast Cancer Therapies Present and Future.” Journal of Cancer Therapy 3: 1140-50.

Maimela, Nomathamsanqa Resegofetse, Shasha Liu, and Yi Zhang. 2019. "Fates of CD8+ T Cells in Tumor Microenvironment." Computational and Structural Biotechnology Journal 17: 1-13. https://doi.org/10.1016/j.csbj.2018.11.004.

Miyoshi, Yuichiro et al. 2019. “Associations in Tumor Infiltrating Lymphocytes between Clinicopathological Factors and Clinical Outcomes in Estrogen Receptor Positive / Human Epidermal Growth Factor Receptor Type 2 Negative Breast Cancer.” Oncology Letters 17: 2177-86.

Mohamed, Mahmoud et al. 2016. "CD8 + Tumor Infiltrating Lymphocytes Strongly Correlate with Molecular Subtype and Clinico-Pathological Characteristics in Breast Cancer Patients from Sudan.” Translational Medicine Communications: 4-9. http://dx.doi.org/10.1186/s41231-016-0005-1.

Najmuddin, Syed Umar Faruq syed, Muhammad Firdaus Romli, Muhajir Hamid, and Noorjahan Banu Alitheen. 2016. "Anti-Cancer Effect of Annona Muricata Linn Leaves Crude Extract ( AMCE ) on Breast Cancer Cell Line.” BMC Complementary and Alternative Medicine 16(311): 1-20.

Setyorini, Herni Asih, Arifayu Addiena Kurniatri, Rosa Adelina, and Adelina Adelina. 2016. "Karakterisasi Mutu Ekstrak Daun Sirsak (Annona Muricata L.) Dari Tiga Tempat Tumbuh.” Buletin Penelitian Kesehatan 44(4): 279-86.

Stachs, Angrit, Johannes Stubert, Toralf Reimer, and Steffi Hartmann. 2019. "Benign Breast Disease in Women.” Dtsch Arztebl Int 116: 565-74.

Visscher, Daniel W, Aziza Nassar, Amy C Degnim, and Marlene H Frost. 2014. "Sclerosing Adenosis and Risk of Breast Cancer." Breast Cancer Res Treat: 1-9.

Wongso, Hendris, and Iswahyudi. 2013. "Induksi Kanker pada Tikus Putih Spraque Dawley sebagai Hewan Model dalam Penelitian Radiofarmaka.” Prosiding Seminar Nasional Sains dan Teknologi Nuklir: 319-26.

Zgura, Anca, Laurentia Gales, Elvira Bratila, and Rodica Anghel. 2018. "Relationship between Tumor Infiltrating Lymphocytes and Progression in Breast Cancer." MAEDICA - a Journal of Clinical Medicine 13(4): 317-20.

\begin{tabular}{|l|r|}
\hline Submission & 16 Januari 2020 \\
\hline Review & 17 Juli 2020 \\
\hline Accepted & 08 September 2020 \\
\hline Publish & 26 Oktober 2020 \\
\hline DOI & 10.29241/jmk.v\%vi\%i.296 \\
\hline Sinta Link & https://sinta.ristekbrin.go.id/journals/detail?id=3576 \\
\hline
\end{tabular}

